\title{
Analysis \& Design of Parabolic Trough Solar Thermal Power Plant for Typical Sites of Pakistan
}

\author{
Engr. Shahrukh Saleem ${ }^{1}$, Prof. Dr. Azzam ul Asar ${ }^{2}$ \\ ${ }^{I}$ Department of Electrical Engineering, University of Engineering \& Technology, Peshawar, Pakistan \\ ${ }^{2}$ Department of Electrical Engineering, University of Engineering \& Technology, Peshawar, Pakistan
}

\begin{abstract}
This paper investigates the feasibility of a Parabolic Trough Solar Thermal Power Plant (PTSTPP) for typical sites of Pakistan. The solar resource of the country is assessed against the required insolation levels. An optimum potential site with suitable irradiance level is identified and evaluated on the basis of certain parameters like wind speed, slope, land use, transmission lines, road \& railway network, water resources \& natural gas availability etc. A location near Nawabshah in Nara desert with total annual direct normal irradiance (DNI) of $2057.6 \mathrm{kWh}$ per $\mathrm{m}^{2}$ was found suitable for the construction of PTSTPP. A 30MW PTSTPP without any thermal energy storage is proposed on the selected site. The design comprises 56 collector loops with 4 parabolic trough collectors (PTC) per loop. The proposed design is verified with the help of simulation. The designed plant can generate $31.54 \mathrm{MW}$ net on an average day in the month of June. The levelized cost of electricity $(L C O E)$ is found to be 15.47 cents per $\mathrm{kWh}$. The capacity factor of the proposed power plant comes out to be $20.5 \%$. Cost comparison with conventional fossil fuel \& renewable energy power plants already operational in Pakistan predicts that the proposed PTSTP plant can compete well in the current energy market of the country.
\end{abstract}

Keywords: concentrated solar power (CSP), direct normal irradiance (DNI), insolation, parabolic trough, solar thermal power (STP)

\section{Introduction}

The drastically increasing global energy demand and the substantial use of fossil fuels for power generation have affected the globe adversely. On the other hand the limited resources of conventional fuels as well as unstable oil prices have forced the world to find the alternative and sustainable energy resources. Fossil fuels dominate the present power generation matrix of Pakistan. The total installed capacity of electricity is about $21376 \mathrm{MW}$ of which $62.4 \%$ is based on oil \& gas. A power shortfall of 4000-5000 MW on average is prevailing in the country [1].

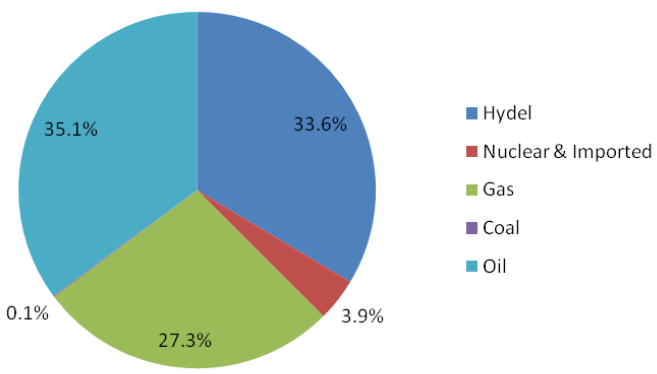

Figure 1 Electricity Generation mix of Pakistan [1]

The Renewable Energy policy 2006 of Pakistan has set a goal of 5\% of the total power generation to be obtained with alternate energy resources by year 2030. There is an extra ordinary alternate energy resource potential in Pakistan which can be utilized to overcome the energy shortage and to meet the country green energy goals in a suitable and economical way.

Solar energy is the most readily available \& widely distributed alternate energy resource. Concentrated solar power (CSP) technologies are one of the best options to utilize this energy. The CSP systems make use of concentrating mirrors to collect the sunlight as heat. This collected heat raises the temperature of a working fluid significantly high. A conventional thermal power block extracts the heat from working fluid and drives a steam engine. Based on different mirror configurations, CSP plants have three design types: solar power towers, dish sterling and parabolic troughs. Each design alternative has its own merits and demerits but parabolic trough has 
proven to be the most mature and economical technology currently available [2]. The main disadvantage associated with the solar power tower and dish sterling is their complex dual-axis sun tracking mechanism which increases their cost of development while in parabolic trough design a large array of reflectors can share one tracking axis. It should be noted that more than $70 \%$ of the total globally operational CSP plants use parabolic trough technology. Such power plants use curved mirror troughs which concentrate the sunlight onto a steel tube containing a heat transfer fluid running along the focal line of the reflectors. The collectors track the sun on a single axis. A fluid passes through the receiver and its temperature rises above $400{ }^{\circ} \mathrm{C}$. The fluid containing the heat is transported to a steam engine where about one third of the heat is converted to electricity [3]. According to Green Peace International report, the desert regions of Pakistan are among the most suitable areas of the world for solar thermal power (STP) generation [4]. Hence PTSTPP could be constructed in Pakistan with lower financial risks and better production results.

\section{Required conditions for constructing PTSTPP}

The site selection for constructing a PTSTPP is subject to some essential requirements which must be fulfilled in order to ensure the economical power generation. These conditions are as follows:

- Direct Normal Irradiation (DNI) $>1900 \mathrm{kWh} / \mathrm{m}^{2} /$ year $\left(5.2 \mathrm{kWh} / \mathrm{m}^{2} /\right.$ day $)$ [5]

- One axis sun tracking mechanism to maximize the incident solar radiation.

- Flat land area with an overall slope of less than 1 - 3\% [6]

The intensity of solar radiation is essentially controlled by the ground slope on a certain location [7]. The land slope gives rise to factors like self-shadowing and shading cast by the nearby terrain which significantly reduces the amount of radiation intercepted by the collectors. Hence land with higher slope affects the performance of a solar plant.

- Wind speed $<15.64 \mathrm{~m} / \mathrm{s}$ [8]

The support structure of solar collector assembly is designed to withstand certain wind load. The performance and structural design of solar field are affected by high winds. Hence high-wind sites limit the performance potential of the solar plant. [8]

- Availability of convenient grid connection

- Availability of water resources

- Availability of good transportation facilities

- Availability of back up fuel (optional)

\section{Resource Assessment of Pakistan for constructing PTSTPP}

Pakistan lies in a region of high solar radiation. On average, $5-7 \mathrm{kWh} / \mathrm{m}^{2} /$ day of insolation exists in the country over more than $95 \%$ of its area with persistence factor of over $85 \%$ [9]. Most parts of the country receive about 8 to 10 sunshine hours per day. Fig. 2 shows the annual DNI map of Pakistan.

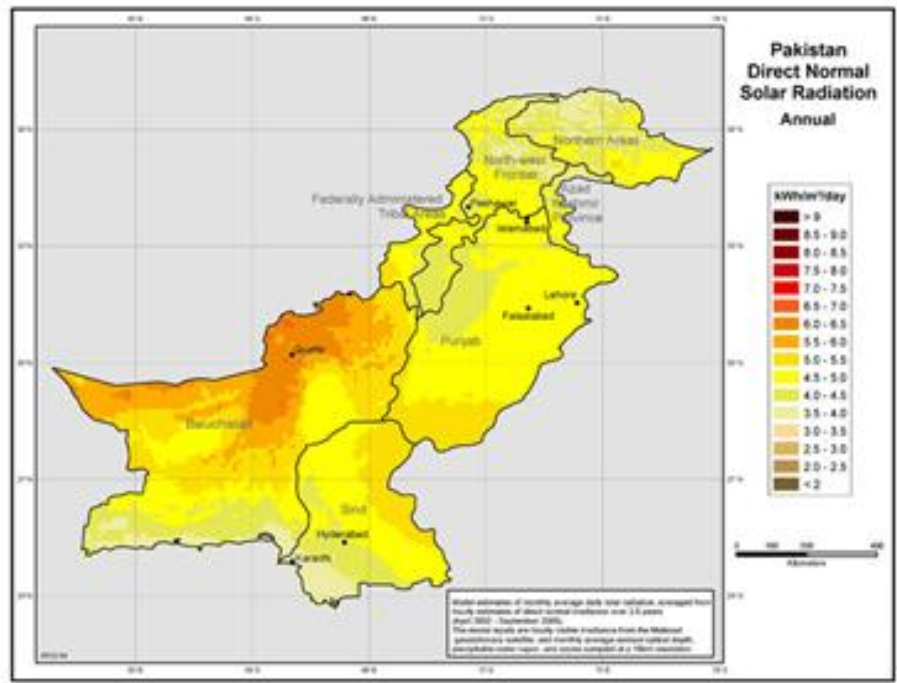

Figure 2 Annual DNI map of Pakistan [10]

In this paper, the site selection procedure for constructing PTSTPP is divided into two phases. In the $1^{\text {st }}$ phase, some primary conditions are considered to narrow down the search domain. A location selected in the $1^{\text {st }}$ phase with optimum favorable characteristics is then evaluated for some secondary essential requirements. For 
collecting these data sets, geographical maps of Pakistan, Geo-Spatial Toolkit developed by National Renewable Energy Laboratory (NREL) and Google Earth tool have been used.

Phase - I of the site selection considers the following conditions to be fulfilled simultaneously:

- $\quad \mathrm{DNI} \geq 5.2 \mathrm{kWh} / \mathrm{m}^{2} /$ day

- Ground Slope $\leq 3 \%$

- Land use: Barren or sparsely vegetated

The Geo-Spatial toolkit developed by NREL for Pakistan gives the results in the form of customized DNI map in which all the regions qualifying the desired criterion of Phase-I are highlighted. The regions which failed to meet the required conditions are excluded from the map and are represented in white color. Fig. 3 depicts the potential sites of Pakistan for developing PTSTPP.

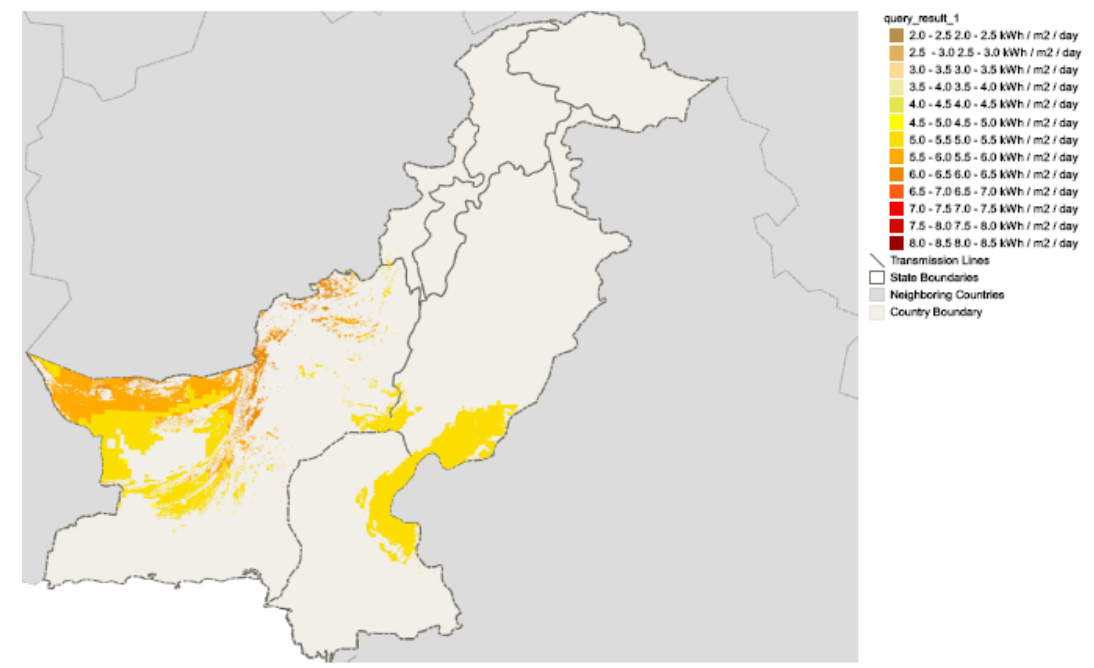

Figure 3 Geo Spatial Toolkit Results

Based on Fig. 3, the shortlisted sites are given in Table 1.

Table 1 Shortlisted sites based on the results of Geo-Spatial toolkit

\begin{tabular}{|c|c|c|}
\hline Balochistan & Punjab & Sindh \\
\hline Chagai & Cholistan & Ghotki \\
\hline Panjgur & Bahawalpur & Khairpur \\
\hline Quetta & D.G.Khan & $\begin{array}{c}\text { Nawabshah } \\
\text { (Nara) }\end{array}$ \\
\hline Qila Abdullah & $\begin{array}{c}\text { Raheem Yar } \\
\text { Khan }\end{array}$ & Sanghar \\
\hline
\end{tabular}

Availability of solar radiation data is of critical requirement for analyzing any solar thermal power technology. Hourly DNI values for a certain site in a standard format, mostly TMY2 (Typical Meteorological Year version 2) are required to be used with any software tool. Keeping in view the potential sites given in Table 1 and the availability of climatological data, the sites with the highest value of annual DNI have been selected. For this purpose, the required radiation data has been taken from a meteorological database called METEONORM [11]. Based on the above mentioned site selection criteria and the radiation data availability limitations, the search domain for the siting of PTSTPP finally reduced to three potential sites as given in Table 2 .

Table 2 Annual DNI values for potential sites

\begin{tabular}{|c|c|}
\hline Name of the Site & $\begin{array}{c}\text { DNI } \\
\mathbf{K w h} / \mathbf{m}^{2} / \text { year }\end{array}$ \\
\hline $\begin{array}{c}\text { Nawabshah } \\
\text { (Nara Desert) }\end{array}$ & 2057.6 \\
\hline Quetta & 1945.5 \\
\hline Raheem Yar Khan & 1924.6 \\
\hline
\end{tabular}

A location in Nara desert near District Nawabshah in the province of Sindh with highest level of insolation seems to be optimum for siting the proposed PTSTPP.

In Phase-II, other essential requirements are investigated specifically with reference to Nawabshah. The required parameters are summarized in Table 3. 
Table 3 Summary of the required parameters near the selected site of Nawabshah

\begin{tabular}{|c|c|}
\hline $\begin{array}{c}\text { Required } \\
\text { Parameter }\end{array}$ & Availability \\
\hline Water Resources & $\begin{array}{c}\text { Nara Canal }(8 \mathrm{~km}) \\
\text { Chotiari Dam }(37 \mathrm{~km})\end{array}$ \\
\hline Grid Connection & $132 \mathrm{kV}$ Sanghar $(\sim 50 \mathrm{~km})$ \\
\hline Wind Speed & $0-5.4 \mathrm{~m} / \mathrm{s}$ \\
\hline Transportation & $\begin{array}{c}\text { Nawabshah Railway station }(62 \mathrm{~km}) \\
\text { Sanghar road }(12 \mathrm{~km})\end{array}$ \\
\hline $\begin{array}{c}\text { Backup Fuel } \\
\text { (Natural Gas) }\end{array}$ & $\begin{array}{c}\text { Sawan gas field }(60.82 \mathrm{~km}) \\
\text { Kadanwari gas field } \\
(77.18 \mathrm{~km})\end{array}$ \\
\hline
\end{tabular}

The final selected site is shown in Fig. 4.

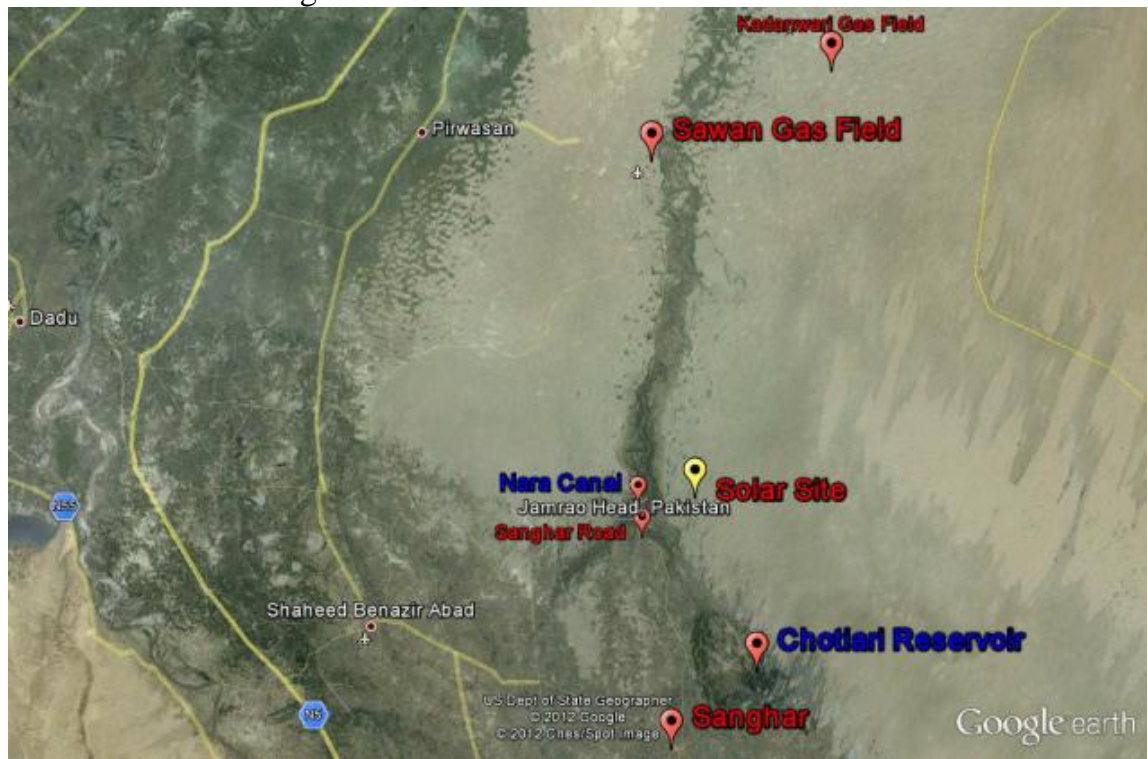

Figure 4 Selected site for the construction of PTSTPP

\section{Mathematical modeling \& Simulation}

The next step after siting the PTSTPP is the determination of the optimum design for the plant. In this paper, the model of Duffie \& Beckmen (2005) [12] is referred which states that for a single concentrating collector, the useful heat gain Qu can be expressed as,

$$
Q_{u}=F_{R} A_{a}\left[S-A_{r} / A_{a} U_{L}\left(T_{i}-T_{a}\right)\right]
$$

Where $F_{R}$ is collector heat removal factor, $A_{a}$ is aperture area of concentrator, $A_{r}$ is receiver area, $S$ is absorbed solar radiation, $\mathrm{U}_{\mathrm{L}}$ is heat loss coefficient, $\mathrm{T}_{\mathrm{i}}$ is fluid inlet temperature, $\mathrm{T}_{\mathrm{a}}$ is ambient temperature.

Literature survey reveals that the design point for parabolic trough solar field is 21 st June, 12 'o' clock in the noon [13]. The proposed PTSTPP design incorporates Parabolic Trough Concentrator (PTC) Euro Trough ET-150 [14], Heat Collecting Element (HCE) Solel UVAC3 [15] and Heat Transfer Fluid (HTF) Therminol VP1 [16]. The incident radiation on the selected site at design point is $960 \mathrm{~W} / \mathrm{m}^{2}$. Solving equation 1 for the design point gives the useful heat gain to be,

\section{$\mathrm{Qu}=549.120 \mathrm{~kW}$ per collector}

The output temperature of a collector is given by [13],

$$
\mathbf{T}_{\mathrm{o}}=\mathbf{T}_{\mathrm{i}}+\mathbf{Q u} / \mathbf{m}^{\prime} \mathbf{c}_{\mathrm{p}}----2
$$

Where $T_{o}$ is outlet temperature, $T_{i}$ is inlet temperature $\left(293{ }^{\circ} \mathrm{C}\right.$ in our case), $\mathrm{m}^{\prime}$ is mass flow rate of HTF ( $8 \mathrm{~kg} / \mathrm{s}$ nominal) and $\mathrm{c}_{\mathrm{p}}$ is specific heat capacity of HTF. Solving equation 2 shows that a single collector gives a rise of $28.2{ }^{\circ} \mathrm{C}$ in the temperature of HTF. Hence for the desired outlet temperature of $393{ }^{\circ} \mathrm{C}$, (a total rise of $100{ }^{\circ} \mathrm{C}$ ) 
Rounding off to a practical figure,

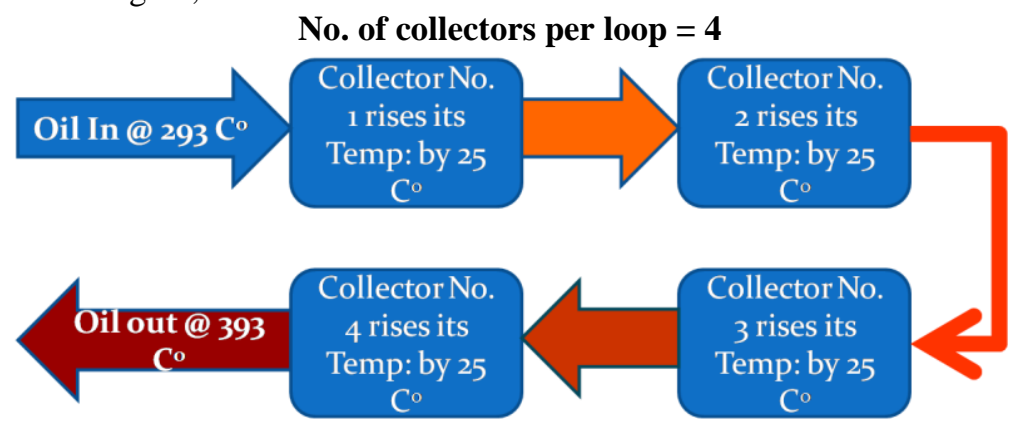

Figure 5 A collector loop raising the temperature of HTF by $100{ }^{\circ} \mathrm{C}$

Fig. 5 shows the collector loop configuration to give a total rise of $100{ }^{\circ} \mathrm{C}$ in the HTF temperature. A PTSTPP of $30 \mathrm{MW}$ net capacity with electrical generator efficiency $=0.96$ (nominal), boiler efficiency $=0.90$ [2], turbine efficiency $=0.37$ [2], electrical parasitics $=5.8 \mathrm{MW}$ [17], solar field piping losses $=6.2 \mathrm{MW}_{\text {th }}$ [17] requires a total of $118.2 \mathrm{MW}_{\text {th }}$ from its solar collector field. The total no. of collector loops required to provide this much of thermal energy is given by [13],

\section{No. of loops required $=\left(\mathbf{P}_{t h} /\right.$ Output power per collector $) /$ No. of collectors per loop}

Hence 54 no. of loops are sufficient to generate a $30 \mathrm{MW}$ net of output power from the proposed PTSTPP on the design point. An "I" field layout is selected for the collector field [18] which requires an equal no. of collector distribution to ensure uniform hydraulic balance in the system Hence no. of collector loops is increased to 56. Calculating the output power generated with 56 no. of loops gives $31.54 \mathrm{MW}$ net. The "I" layout of the solar collector field is shown in Fig. 6.

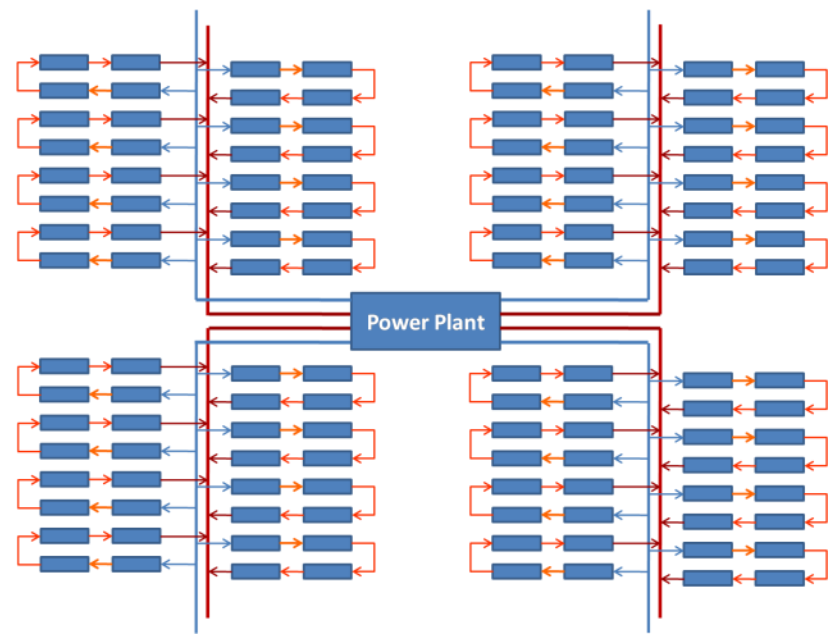

Figure 6 Solar Field Layout

Duffie \& Beckmen [12] represent a month by an average day of that month. It has made the solar power generation calculations much easier since power generation trend on the average day of a month will represent the generation pattern for the whole month. Table 4 represents the hourly generated output power of the proposed PTSTTPP on an average day of each calendar month.

Table 4 Output power for the month of Jan - Dec on an average day.

\begin{tabular}{|c|c|c|c|c|c|c|c|c|c|c|c|c|}
\hline \multirow{2}{*}{$\begin{array}{l}\text { Time } \\
\text { Hrs }\end{array}$} & \multicolumn{12}{|c|}{ Hourly Output Power Generated, MW } \\
\hline & $\begin{array}{c}17 \\
\text { Jan }\end{array}$ & $\begin{array}{c}16 \\
\text { Feb }\end{array}$ & $\begin{array}{c}16 \\
\text { Mar }\end{array}$ & $\begin{array}{c}15 \\
\text { Apr }\end{array}$ & $\begin{array}{c}15 \\
\text { May }\end{array}$ & $\begin{array}{c}11 \\
\text { Jun }\end{array}$ & $\begin{array}{c}17 \\
\text { Jul }\end{array}$ & $\begin{array}{c}16 \\
\text { Aug }\end{array}$ & $\begin{array}{c}15 \\
\text { Sep }\end{array}$ & $\begin{array}{c}15 \\
\text { Oct }\end{array}$ & $\begin{array}{c}14 \\
\text { Nov }\end{array}$ & $\begin{array}{c}10 \\
\text { Dec }\end{array}$ \\
\hline 0500 & 0.00 & 0.00 & 0.00 & 0.00 & 0.00 & 0.00 & 0.00 & 0.00 & 0.00 & 0.00 & 0.00 & 0.00 \\
\hline 0600 & 0.00 & 0.00 & 0.00 & 0.00 & 0.00 & 0.00 & 0.00 & 0.00 & 0.00 & 0.00 & 0.00 & 0.00 \\
\hline 0700 & 0.00 & 0.00 & 0.00 & 0.00 & 0.00 & 0.00 & 0.00 & 0.00 & 0.00 & 0.00 & 0.00 & 0.00 \\
\hline 0800 & 0.00 & 0.00 & 0.00 & 0.00 & 3.72 & 3.81 & 0.00 & 0.00 & 0.00 & 0.00 & 0.00 & 0.00 \\
\hline 0900 & 0.00 & 1.98 & 0.24 & 16.02 & 16.63 & 19.03 & 13.78 & 11.08 & 8.31 & 5.92 & 5.61 & 0.00 \\
\hline 1000 & 7.14 & 14.00 & 5.92 & 23.24 & 26.50 & 26.34 & 22.09 & 22.19 & 16.08 & 20.08 & 16.45 & 8.25 \\
\hline 1100 & 18.50 & 22.95 & 15.72 & 28.61 & 27.78 & 30.28 & 27.53 & 25.56 & 17.14 & 25.70 & 23.36 & 20.97 \\
\hline
\end{tabular}


Analysis \& Design of Parabolic Trough Solar Thermal Power Plant for Typical Sites of Pakistan

\begin{tabular}{|c|c|c|c|c|c|c|c|c|c|c|c|c|}
\hline 1200 & 24.22 & 26.17 & 19.58 & 30.84 & 31.67 & 31.95 & 30.56 & 30.56 & 23.84 & 28.34 & 23.72 & 19.97 \\
\hline 1300 & 24.56 & 28.17 & 22.26 & 31.67 & 31.67 & 32.45 & 31.39 & 31.39 & 24.97 & 30.56 & 31.39 & 19.42 \\
\hline 1400 & 25.45 & 28.22 & 24.34 & 30.84 & 31.11 & 31.39 & 31.45 & 31.11 & 22.72 & 27.25 & 22.84 & 17.78 \\
\hline 1500 & 21.81 & 24.00 & 21.45 & 28.06 & 28.89 & 28.34 & 28.34 & 27.39 & 22.00 & 24.17 & 17.97 & 5.61 \\
\hline 1600 & 12.08 & 18.61 & 19.33 & 24.28 & 16.25 & 24.53 & 24.25 & 23.36 & 16.75 & 15.72 & 10.42 & 0.17 \\
\hline 1700 & 0.00 & 5.26 & 0.51 & 11.70 & 16.33 & 17.56 & 16.22 & 15.53 & 0.07 & 1.89 & 0.00 & 0.00 \\
\hline 1800 & 0.00 & 0.00 & 0.00 & 0.00 & 2.05 & 1.98 & 2.59 & 0.85 & 0.00 & 0.00 & 0.00 & 0.00 \\
\hline 1900 & 0.00 & 0.00 & 0.00 & 0.00 & 0.00 & 0.00 & 0.00 & 0.00 & 0.00 & 0.00 & 0.00 & 0.00 \\
\hline 2000 & 0.00 & 0.00 & 0.00 & 0.00 & 0.00 & 0.00 & 0.00 & 0.00 & 0.00 & 0.00 & 0.00 & 0.00 \\
\hline
\end{tabular}

TRNSYS Tool \& STEC Library are developed by the University of Wisconsin for the transient simulation of systems. The design for the proposed PTSTPP is simulated with the help of TRNSYS Tool \& STEC Library. The simulation model for the proposed PTSTPP is shown in Fig. 7.

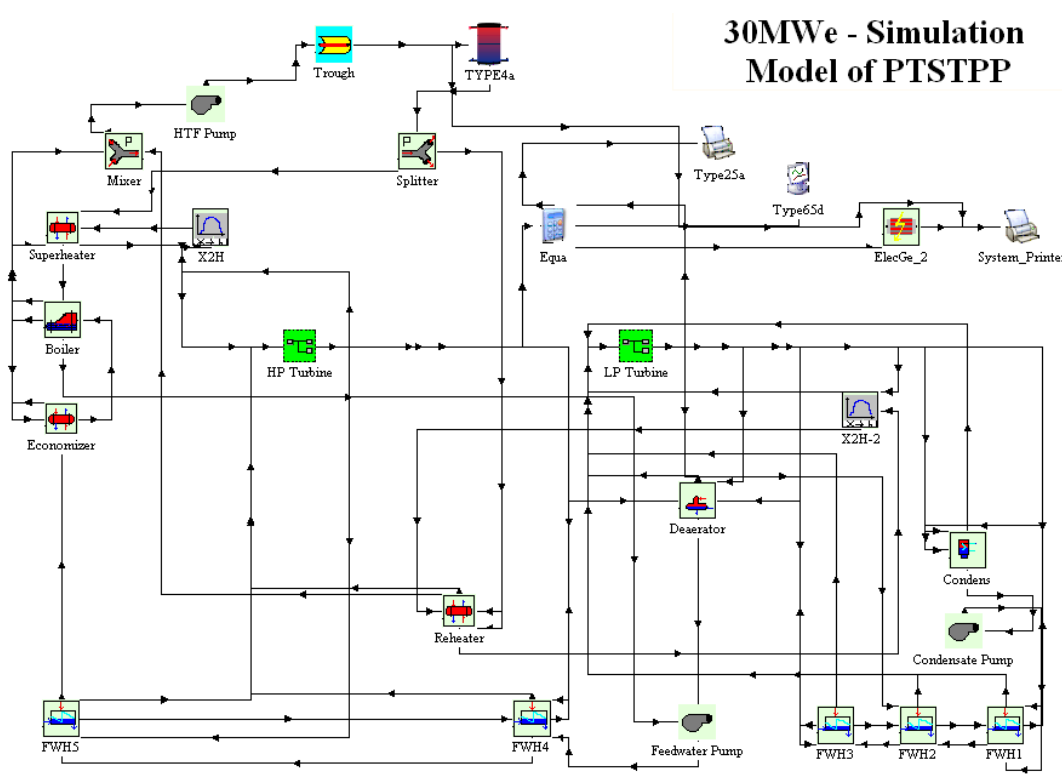

Figure 7 Simulation model for proposed PTSTPP

The simulation model on design point gives a net output power of 31.114 MW which is in good accordance with the calculated value.

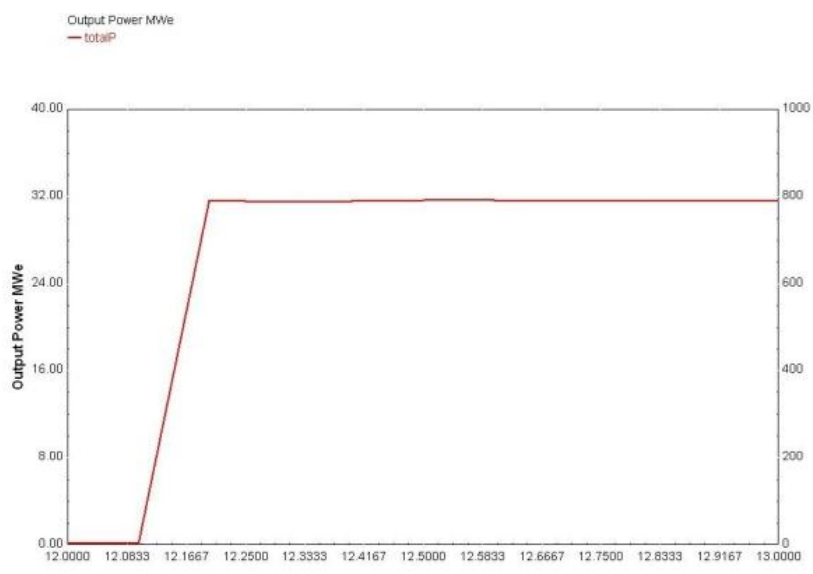

Figure 8 Output Power of PTSTPP using TRNSYS

\section{Economic Viability of PTSTPP in Pakistan}

The Levelized cost of Electricity (LCOE) is considered as the yard stick to compare different power generation technologies. Assuming the financial analysis period of 30 years, current inflation rate of $7.9 \%$, real discount rate of $9.50 \%$, loan rate of $9.5 \%$ and incorporating these local factors in the Financial Reference Model developed by National Renewable Laboratory NREL $[19,20]$ gives a LCOE of 15.47 cents/kWh and a capacity factor of $20.5 \%$. These results are in well accordance with the published data of LCOE $=14-36$ cents $/ \mathrm{kWh}$ and 
capacity factor $=20-25 \%$ [21]. The proposed plant can generate 54904.4 MWh (gross) of electrical energy per year. Although the LCOE of the proposed PTSTPP is higher than the other natural gas power plants in Pakistan but it should be noted that National Transmission \& Dispatch Company (NTDC) is generating electricity from Muzaffargarh power house unit no. $5 \& 6$ at 22.00 cents/kWh [22]. Similarly NTDC is purchasing electricity at LCOE of 16.109 cents/kWh from FFC Wind Power Plant [23]. Hence the proposed PTSTPP can well compete with the conventional thermal as well as other renewable energy power plants in the country.

\section{Conclusion}

This paper presented the parabolic trough solar thermal power technology as one of the best solutions for Pakistan to meet its energy shortfall and to achieve its green energy goals. It was found that there are a number of locations in the country with excellent solar resource and other favorable characteristics which are best suited for the development of STP generation. Places like Chagai, Quetta, Cholistan, Bahawalpur, D.G.Khan, Nara, Khairpur, Nawabshah and Sanghar are few of them. Economic analysis of the proposed PTSTP plant shows that solar thermal power can compete well with conventional fossil fuel and renewable energy power plants in the energy market of Pakistan. Although even a single power plant has not yet been built up, once Pakistan learns the technology through study and improvement, such technology can be widely used with relatively cheaper cost with the country conditions. Constructing PTSTPP will become a milestone in the development of Pakistan's solar thermal power industry. On the other hand the wide commercial application of parabolic trough technology is expected to be a new growth point in Pakistan's power economy.

\section{References}

[1] Pakistan Energy Yearbook 2011, Ministry of Petroleum \& Natural resources, Hydrocarbon Development Institute of Pakistan. www.hdib.org.pk

[2] Al-Nasser, A.M, Performance and Economics of a Solar Thermal Power Generation Plant in Jubail, Saudi Arabia: Parabolic Trough Collector, IEEE International Energy Conference and Exhibition (EnergyCon), 2010.

[3] Status Report on Solar Trough Power Plants, Pilkington Solar International GmbH, Sponsored by the German Federal Minister for Education, Science, Research and Technology,

[4] Solar Thermal Power 2020, URL: http://www.greenpeace.org/international/en/publications/reports/solar-thermal-power-2020/

[5] Mingzhi Zhao; Zhizhang Liu; Qingzhu Zhang; Feasibility Analysis of Constructing Parabolic Trough Solar Thermal Power Plant in Inner Mongolia of China, APPEEC 2009, Asia-Pacific Power and Energy Engineering Conference, 2009.

[6] Bin Yang; Jun Zhao; Wenbin Yao; Qiang Zhu; Hang Qu, Feasibility and Potential of Parabolic Trough Solar Thermal Power Plants in Tibet of China, APPEEC 2010, Asia-Pacific Power and Energy Engineering Conference 2010

[7] Richard G. Allen, Ricardo Trezza, Masahiro Tasumi, Analytical integrated functions for daily solar radiation on slopes, Agricultural and Forest Meteorology 139 (2006) 55-73

[8] Nusrat Kamal Raja, M. Shahid Khalil, Syed Athar Masood, Muhammad Shaheen, Design and Manufacturing of Parabolic Trough Solar Collector System for a Developing Country Pakistan, Journal of American Science, 2011.

[9] Munawar A. Sheikh, Renewable and Sustainable Energy Reviews, Energy and renewable energy scenario of Pakistan, Journal of Science Direct, 2009.

[10] Dr. Muhammad Shahid Khalil, Renewable Energy in Pakistan: Status and Trends by, University of Engineering \& Technology Taxila,

[11] About METEOTEST and meteonorm, URL: http://meteonorm.com/about-us/meteotest/

[12] Duffie, J.A. and Beckman, W.A, Solar Engineering of Thermal Processes, $3^{\text {rd }}$ Edition New York, USA 2005.

[13] Spiru Paraschiv, Simona Lizica Paraschiv, Ion V. ION, Nicuşor, Design and sizing characteristics of a solar thermal power plant with cylindrical parabolic concentrators in Dobrogea region, VATACHI, TERMOTEHNICA 2, 2010

[14] Montes, M., Abánades, A., Martínez-Val, J., and Valdés, M, Solar multiple optimization for a solar-only thermal power plant, using oil as heat transfer fluid in the parabolic trough collectors, Solar Energy, 83(12), pp. 2165 - 2176. 2009

[15] Ricardo Vasquez Padilla, Simplified Methodology for Designing Parabolic Trough Solar Power Plants, University of South Florida, 2011.

[16] Therminol VP-1, Heat Transfer Fluids by SOLUTIA, Applied Chemistry Creative Solutions.

[17] Frank Lippke, Simulation of the Part-Load Behavior of a 30 MWe SEGS Plant, Solar Thermal Technology Department, Sandia National Laboratories, 1995.

[18] B. Kelly, D. Kearney, Parabolic Trough Solar System Piping Model, Subcontract Report NREL/SR-550-40165 July 2006

[19] C. Turchi, Parabolic Trough reference plant for cost modeling with the Solar Advisor Model (SAM), Technical Report NREL/TP550-47605 July 2010.

[20] System Advisor Model (SAM), URL: https://sam.nrel.gov/

[21] International Renewable Energy Agency, Renewable energy technologies: cost analysis series, Volume 1: Power Sector, Issue 2/5, IRENA Working Paper, June 2012.

[22] Merit Order - February 2014, National Power Control Center, Islamabad.

[23] RE Tariff - Alternative Energy Development Board Ministry of Water and Power Government of Pakistan, URL: http://www.aedb.org/Main.htm 